The Federation of Women's Clubs, Mothers' Congress, the Consumers' League and various local organizations are all co-operating to this end.

Eleven different types of literature have been distributed, some in 30,000 quantities, bearing upon the issues of the campaign. The prospects are encouraging for a bill which will stop parental perjury and give school officials the issuance of certificates, but determined opposition has already shown itself to the ten-hour day and the abolition of night-work provisions in our second bill. Another court decision-the fourth within four yearshas overthrown an additional part of the existing child labor law. This, however, only makes the passage of our bills more necessary.

Fred S. HaLL, Secretary.

\title{
ALLEGHENY COUNTY (PA.) CHILD LABOR ASSOCIATION.
}

The Chairman of the Legislative Committee of the Child Labor Association of Allegheny County, Pennsylvania, has authorized me to make the following report of the work done by this Association:

Since April, 1908, the Association has been occupied mainly in working in co-operation with the Pennsylvania Child Labor Association in framing bills to be presented to the Legislature now in session. Since December Ist, active measures have been taken to create public opinion throughout the district and in organizing the work here. The services of a directing secretary have been secured to extend the work.

Alida Lattimore, Directing Secretary.

\section{THE RHODE ISLAND JOINT COMMITTEE ON CHILD LABOR.}

The Joint Committee on Child Labor-formed in Rhode Island in January, 1908, and composed of representatives of local educational and philanthropic societies, as well as sub-committees of the Rhode Island State Child Labor Committee-is continuing during the present winter its active campaign for an improved child labor law. A bill amending the law in four particulars was introduced in the assembly in 1908 . It passed the House, but failed of passage in the Senate. A bill similar in its provisions has been introduced this year and is now in the hands of the Senate committee on special legislation. A public hearing on the bill is promised within a few days. Meanwhile the Rhode Island State Federation of Women's Clubs has published a simplified statement of the present Factory Inspection Law of the state, which controls the labor conditions of the women and children, and has also supplemented the statement with the amendments proposed to the present law and the reasons why such amendments are deemed wise and practicable, asking each member of the Federation to bring these amendments and the arguments in their favor to the attention of their local representatives in our assembly. 
The Committee is hoping for the successful passage this year of these four amendments:-rst. 7 p. m. instead of $8 \mathrm{p}$. m. shall end the day's work for children under sixteen years of age in all factories, manufacturing or business establishments. 2d. The privilege now held by mercantile establishments of keeping children under sixteen years of age late on Saturday nights and for the four days preceding Christmas shall be withdrawn. 3d. An educational test, viz., the ability to read and write simple sentences in English, before granting working certificates to children under sixteen years of age. 4th. The employer of a child who claims to be sixteen years of age but whose appearance causes the factory inspector to doubt it, shall be required to furnish satisfactory proof of the claim.

Mrs. Carl Barus,

Chairman.

\section{CITIZENS' CHILD LABOR COMMITTEE, WASHINGTON, D. C.}

A law for the regulation of child labor in the District of Columbia was passed by the National Congress and approved by the President on May 28 th, of last year. This law is the result of three and a half years' effort on the part of the National Committee and of the local Committee organized at the suggestion of the National Committee. The law as passed contains some features which were opposed by the friends of the measure, but which finally had to be accepted. The measure was passed practically in the shape recommended by the National and local Committees, with several sections added which regulated street trading on the lines of the New York law. A proviso was inserted by the Senate permitting the judge of the Juvenile Court to exempt children under the limit of fourteen years, but over twelve years of age, if they were the support of dependent relatives.

Unfortunately the appropriation bill as passed by Congress contained no provision for the inspectors authorized by the act. The Commissioners of the District did the best they could under the circumstances by detailing two policemen for this duty, and these officers are engaged in filling these positions at the present time. Owing to the lack of appropriations, it was not possible to announce the enforcement of the law until August first of last year, and even then, the first month was taken up in the preliminary work of explaining the provisions of the law to dilatory employers and parents. The actual enforcement of the law therefore took place about the first of September, 1908. The following report on the effect of the law refers only to the four months ending December 3Ist, 1908.

For this period, the most important event has been the work of providing the children with age and schooling certificates. The law provides that these certificates shall be issued by the school board and experience seems to show that for this jurisdiction the school authorities are best qualified to perform this duty. The age of children is secured for school purposes some time before the question of employment arises and is therefore likely to be reported correctly. By requiring each applicant for an employment certificate to bring with him his last school report, the officials 